Sains Malaysiana 50(8)(2021): 2251-2269

http://doi.org/10.17576/jsm-2021-5008-10

\title{
Preparation of Alpinia galanga Stem Based Activated Carbon via Single-step Microwave Irradiation for Cationic Dye Removal
}

(Penyediaan Karbon Teraktif Berasaskan Batang Alpinia galanga dengan Penyinaran Gelombang Mikro Satu Langkah untuk Penyingkiran Pewarna Kation)

\author{
N.A. Ahammad, M.F.M. Yusop, A.T. MohD Din \& M.A. AHMAD*
}

\begin{abstract}
The focal point of this study is to synthesis Alpinia galanga Stem-based activated carbon (AGSAC) by using single-step microwave irradiation and testing it for the removal of cationic dye, methylene blue (MB) from aqueous solution. AGSAC was prepared under the flow of carbon dioxide $\left(\mathrm{CO}_{2}\right)$ for the gasification effect. The factors of contact time (from 0 to $24 \mathrm{~h})$ and initial concentration $(25-300 \mathrm{mg} / \mathrm{L})$ on the adsorption performance of AGSAC were studied. With the aid of response surface methodology (RSM) via face-centered composite design (FCD), optimum preparation conditions for $A G S A C$ were found to be $400 \mathrm{~W}$ for radiation power and 4 min for activation time, respectively, which resulted in $95.67 \%$ of $M B$ dye removal. The optimized AGSAC has a Bruneaur-Emmet-Teller (BET) surface area of $172.19 \mathrm{~m}^{2} / \mathrm{g}$, mesopore surface area of $103.32 \mathrm{~m}^{2} / \mathrm{g}$, a total pore volume of $0.1077 \mathrm{~cm}^{3} / \mathrm{g}$, and fixed carbon content of $47.63 \%$. The pore diameter of AGSAC was found to be a mesoporous type with a pore diameter of $2.50 \mathrm{~nm}$. Freundlich isotherm and pseudo-secondorder were found as the best-fitted model for MB adsorption equilibrium and kinetic respectively onto prepared AGSAC. Intraparticle diffusion was found to be the rate-limiting step.
\end{abstract}

Keywords: Activated carbon; adsorption; methylene blue; microwave irradiation; response surface methodology

ABSTRAK

Fokus kajian ini adalah untuk sintesis karbon teraktif berasaskan Batang Alpinia galanga (AGSAC) dengan menggunakan penyinaran gelombang mikro satu langkah dan untuk menguji penyingkiran pewarna kation, metilena biru (MB) daripada larutan berair. AGSAC disediakan di bawah aliran karbon dioksida (CO $\left.{ }_{2}\right)$ untuk kesan gasifikasi. Faktor masa sentuh (dari 0 hingga 24 jam) dan kepekatan awal (25-300 mg/L) pada prestasi penjerapan AGSAC telah dikaji. Dengan bantuan kaedah gerak balas permukaan (RSM) melalui reka bentuk komposit berpusatkan wajah (FCD), keadaan persiapan optimum untuk AGSAC didapati $400 \mathrm{~W}$ bagi kuasa sinaran dan 4 min bagi masa pengaktifan, masingmasing, yang menghasilkan 95.67\% penyingkiran pewarna MB. AGSAC yang dioptimumkan mempunyai luas permukaan Bruneaur-Emmet-Teller (BET) $172.19 \mathrm{~m}^{2} / \mathrm{g}$, luas permukaan mesoliang $103.32 \mathrm{~m}^{2} / \mathrm{g}$, jumlah liang total $0.1077 \mathrm{~cm}^{3} / \mathrm{g}$ dan kandungan karbon tetap 47.63\%. Diameter liang AGSAC didapati jenis mesoliang dengan diameter liang 2.50 $n m$. Freundlich isoterm dan pseudo-peringkat-kedua didapati sebagai model yang paling sesuai untuk keseimbangan penjerapan dan kinetik MB masing-masing pada AGSAC yang telah disediakan. Penyebaran intrazarah didapati sebagai langkah pengehadan kadar.

Kata kunci: Kaedah gerak balas permukaan; karbon teraktif; metilena biru; penjerapan; penyinaran gelombang mikro

\section{INTRODUCTION}

Today, the permeation of material effluents into the water bodies and biological communities remain a particular problem towards the public wellbeing. Among the various chemical effluents contained in industrial wastewater, synthetic ionic dyes cause environmental issues as it restricts sunlight from reaching aquatic life, greatly decreases the water quality of waterways, introduces poisonous chemicals to food chain organisms and carcinogenic substances that are detrimental to human health (Feng et al. 2020; Hameed 
et al. 2017; Kumar 2019; Xu et al. 2020). Even at a very low concentration, dyes are easily seen in water bodies which decrease their aesthetic value. Besides being nonbiodegradable, synthetic dyes are also commonly stable towards heat, light, and chemicals due to the strong and complex aromatic structures that they have. Thus, as dyes migrate through the receiving streams, they will remain in the atmosphere for a very long time. Cationic dye like methylene blue (MB) dissociates in water to produce positive ions which are attracted to the negative polarity region in the molecules of water. As a result, MB is easily soluble in water, thus making the separation process between them a bit challenging. MB was selected in this study because of its harmful properties. Besides increasing the heart beating rate and vomiting, exposure of MB dye towards human on excessive level can harm the skin and causing diseases like cyanosis, jaundice and tissue necrosis (Sadhukhan et al. 2016). Synthetic ionic dyes are coloured compounds which are broadly used in textiles, printing, cosmetics, plastics, leather-based industries to colour their products, consequences in generating a huge quantity of coloured wastewater (Aljeboree et al. 2017; Li et al. 2020; Liu et al. 2020; Shabaan et al. 2020). Due to the increasing demand for products from these industries, the demand for dyes usage is also increased accordingly. Among all the dyes utilizing in industries, textile industries use about 10,000 different dyes, and about $10-15 \%$ of dyes used often discharged into the effluent without any adequate treatment (Damasceno et al. 2020; Kumar 2019; $\mathrm{Xu}$ et al. 2020). This means that the wastewater containing dyes must be treated well and met the standards made by the authorities before being discharged. Therefore, researchers have also made several attempts to establish effective technologies for extracting dyes from industrial wastewater such as adsorption, electrochemical methods, ion exchange, coagulation-flocculation, photo-oxidation, floatation, and membrane filtration (Davarnejad et al. 2020; Ebrahiem et al. 2017; Jabar \& Odusote 2020; Joseph et al. 2020; Lai et al. 2019; Liu et al. 2019; Mahmood et al. 2019; Nippatla \& Philip 2019; Peng et al. 2020). However, most of these technologies are limited by high cost and generation of hazardous materials (Davarnejad et al. 2020).

Among the various techniques that have been implemented, adsorption is the most effective way for dyes removal in terms of its performance, operating expenses, and non-toxicity of the adsorbents used (Hameed et al.
2017; Marrakchi et al. 2016). Generally, the adsorption process occurs via physisorption or chemisorption which involves weak van der Waals forces and covalent or ionic bonding, respectively (Barghi et al. 2014; Ma et al. 2019). Also, the major type of adsorbent used for the adsorption process is silica gel, activated alumina, graphene, activated carbon (AC), zeolites, and nanomaterials (Ajduković et al. 2020; Bhat et al. 2020; Ilnicka et al. 2020; Isawi 2020; Kaminski 2020; Kushwaha et al. 2017). Among all types of adsorbents, AC is considered to be the most superior in eliminating a wide range of pollutants concerning water and wastewater treatment. These pollutants include heavy metals (Köpping et al. 2020; Marwani et al. 2017; Matović et al. 2019; Sabela et al. 2019; Zaini et al. 2020), pharmaceutical residues (Bojić et al. 2017; Guedidi et al. 2020; Kariim et al. 2020; Köpping et al. 2020; Zhao et al. 2020), pesticides (Amézquita-Marroquín et al. 2020; Gonzalez et al. 2020; Marsin et al. 2020; Salman 2014), polycyclic aromatic hydrocarbon (PAH) (Guo et al. 2020; Kumar et al. 2019; Saad et al. 2014; Sullivan et al. 2019), organic compounds (Guillossou et al. 2020; Jović et al. 2020; Rao et al. 2020; Wang et al. 2016), chlorinated hydrocarbon (CHC) (Alhooshani 2019; Schreiter et al. 2018), volatile organic compounds (VOC) (Laskar et al. 2019; Pagalan Jr. et al. 2020; Ushiki et al. 2019; Yao et al. 2020), and dyes (Belayachi et al. 2019; Odogu et al. 2020; Pathania et al. 2017; Sivakumar et al. 2019).

The precursors for AC can be any type of carbonaceous materials such as agricultural waste, woods, nutshells, coconut shells, Alpinia galanga, and other materials that contained amorphous carbon (Shahmoradi et al. 2020; Wang et al. 2020). Adsorbent that has been derived from agricultural waste is better to be developed due to its accessibility and abundant availability and renewable of raw material. Alpinia galanga (Lengkuas) stem is one of the agricultural waste sources available at a very minimal cost. Every year, an estimated million tonnes of agricultural waste was generated in Malaysia. To reduce pollution and landfill volume, this material can be converted to more useful products as mentioned above that will be advantageous to others. Unlike other works that employed 2-stages activation processes (Salem et al. 2020) or physicochemical activation (Habeeb et al. 2020) to produce activated carbon from agricultural waste, this study only focuses on one-stage microwave irradiation technique. To date, there is no work regarding the use of Alpinia galanga as activated carbon was reported. 


\section{MATERIALS AND METHODS}

\section{MATERIALS}

In this study, the Alpinia galanga stem waste was collected from Nibong Tebal area, Pulau Pinang, Malaysia. MB dye is obtained from Sigma-Aldrich (M) Sdn. Bhd. $\mathrm{CO}_{2}$ gas was used as a physical activation agent in this study, with a purity of $99.99 \%$ supplied by MOX-Gases Sdn. Bhd.

\section{OPTIMIZATION OF AGSAC}

The microwave was used to activate the dried precursor by manipulating the power and residence time of the microwave. The activation process occurs under the flow of carbon dioxide gas, $\mathrm{CO}_{2}$. In this experiment, two variables were studied in the preparation of AGSAC which were radiation power, $x_{1}(\mathrm{~W})$ and activation time, $x_{2}(\mathrm{~min})$, whereas the response is MB removal, $\mathrm{y}(\%)$ using Design-Expert software version 8.0.6 (DOE) (STATEASE Inc., Minneapolis, USA. A standard response surface methodology (RSM) design called a facecentered composite design (FCD) was used to analyze the two parameters. The levels and ranges selected for this research are shown in Table 1.

TABLE 1. Independent variables for FCD

\begin{tabular}{|c|c|c|}
\hline Levels & Radiation power (W) & Activation time (min) \\
\hline-1 & 264 & 2 \\
\hline 0 & 440 & 3 \\
\hline+1 & 616 & 4 \\
\hline
\end{tabular}

\section{BATCH EQUILIBRIUM STUDIES}

In the batch study, the amount of adsorption uptake and the dye removal percentage is calculated. For equilibrium studies, the amount of dye adsorbed onto the AGSAC at equilibrium, $\mathrm{q}_{\mathrm{e}}(\mathrm{mg} / \mathrm{g})$, and percentage dye removal (\%) was determined by the following equations (Basu et al. 2018):

$$
\begin{gathered}
q_{e}=\frac{\left(C_{o}-C_{e}\right) V}{W} \\
\text { Dye removal }(\%)=\frac{\left(C_{o}-C_{t}\right)}{C_{o}} \times 100
\end{gathered}
$$

where $C_{o}$ and $C_{e}(\mathrm{mg} / \mathrm{L})$ is the liquid-phase concentrations of adsorbate at initial and at equilibrium, respectively. $C_{t}$ $(\mathrm{mg} / \mathrm{L})$ is the concentration of adsorbate at the time, $\mathrm{t} . \mathrm{V}$ is the volume of the solution (L) and $\mathrm{W}$ is the mass of adsorbent used in this study (g). Sample of MB dye was collected at every time interval by using $3 \mathrm{~mL}$ disposable syringe. UV-Visible spectrometer was used to measure the absorbance of MB dye at the wavelength of 665 $\mathrm{nm}$. The concentration of MB dye was determined from calibration curve that was developed earlier by plotting absorbance versus known concentrations of MB dye. For the analysis of the initial adsorbate concentration and contact time effect on the adsorption uptake, the adsorption temperature of the solution is kept constant at $30{ }^{\circ} \mathrm{C} .25 \mathrm{~mL}$ of respective $\mathrm{MB}$ solutions with a concentration between 25 and $300 \mathrm{mg} / \mathrm{L}$ were arranged in a series of $25 \mathrm{~mL}$ test tubes and $0.025 \mathrm{~g}$ of AGSAC was inserted into each tube. The solutions were placed in the water bath shaker for the shaking process at $30{ }^{\circ} \mathrm{C}$ with $250 \mathrm{rpm}$ of agitation speed until the equilibrium point was reached. All experiment in this study was repeated 3 times and the average values was used. 


\section{ADSORPTION ISOTHERM}

In adsorption isotherm studies, their models were chosen to fit equilibrium data namely, Langmuir, Freundlich, and Temkin. These isotherm models are given by the following expressions (Freundlich 1907; Langmuir 1916; Temkin \& Pyzhev 1940):

$$
\begin{gathered}
\frac{C_{e}}{q_{e}}=\frac{1}{K_{L} q_{m}}+\frac{C_{e}}{q_{m}} \\
\log q_{e}=\log K_{F}+\frac{1}{n} \log C_{e} \\
q e=B \ln A_{T}+B \ln C_{e}
\end{gathered}
$$

where $q_{e}$ is the amount of adsorbate adsorbed per unit mass of adsorbent (mg/g); $q_{m}$ is the adsorption capacity of the adsorbent $(\mathrm{mg} / \mathrm{g}) ; K_{L}$ is the Langmuir adsorption constant related to the free energy adsorption $(\mathrm{L} / \mathrm{mg})$; $K_{F}$ is the Freundlich isotherm constant $[(\mathrm{mg} / \mathrm{g}) .(\mathrm{L} /$ $\left.\mathrm{mg})^{1 / \mathrm{n}}\right]$, which shows the relative adsorption capacity of the adsorbent associated to the bonding energy, $n_{F}$ is the heterogeneity factor exhibiting the divergence from linearity of adsorption, B is $\mathrm{RT} / \mathrm{b}$ constant associated to the heat of adsorption $(\mathrm{L} / \mathrm{mg}), \mathrm{R}$ is the universal gas constant $(8.314 \mathrm{~J} / \mathrm{mol} \mathrm{K})$ and $A$ is equilibrium binding constant $(\mathrm{L} / \mathrm{mg})$.

\section{ADSORPTION KINETIC STUDIES}

In adsorption kinetic analysis, the procedure was identical to batch equilibrium analysis. This study aimed to evaluate the adsorption mechanism of dye from the solution. For kinetic studies, pseudo-first-order and pseudo-second-order models were utilized and were given by the following expressions (Ho \& McKay 1999; Yuh-Shan 2004):

$$
\begin{aligned}
& \ln \left(q_{e}-q\right)=\ln q_{e}-k t \\
& \frac{t}{q_{e}}=\frac{1}{K q_{e} 2}+\frac{1}{q_{e} t}
\end{aligned}
$$

where $k$ is the rate constant of pseudo-first order sorption $(1 / \mathrm{h}) ; k$ is the rate constant of pseudo-second order sorption (g/h.mg).

The number of dyes adsorbed onto the AGSAC at equilibrium, $q_{e}(\mathrm{mg} / \mathrm{g})$ was determined by the following expressions (Basu et al. 2018):

$$
q_{e}=\frac{\left(C_{o}-C_{e}\right) V}{W}
$$

\section{INTRAPARTICLE DIFFUSION MODEL}

The intra-particle diffusion model is used to evaluate the importance of diffusion mechanism as the ratecontrolling step in the adsorption process. The equation for this model is (Weber \& Morris 1963):

$$
q_{t}=k_{p i} t^{1 / 2}+C
$$

where $k_{p i}(\mathrm{mg} / \mathrm{g} \mathrm{h} 1 / 2)$ is the intraparticle diffusion rate constant; and $\mathrm{C}$ is the intercept which is obtained from the slope of the straight line of $\mathrm{q}_{\mathrm{t}}$ versus $\mathrm{t}^{1 / 2} ; q_{t}$ is the quantity of solute adsorbed per unit weight of adsorbent at any time $(\mathrm{mg} / \mathrm{g})$; and $\mathrm{t}^{1 / 2}$ is the half adsorption time, (g/h.mg).

\section{DESORPTION AND REUSABILITY STUDIES}

The studies on desorption and regeneration were carried out in batch mode. Distilled water was used as the desorption eluent. The desorption experiments were conducted in $250 \mathrm{~mL}$ Erlenmeyer flasks using $100 \mathrm{~mL}$ of distilled water as the eluent and $0.1 \mathrm{~g}$ of saturated AGSAC$\mathrm{MB}$. The temperature of the water bath was kept constant at $30{ }^{\circ} \mathrm{C}$. The reusability of the AGSAC-MB was studied by conducting five consecutive adsorption-desorption cycles. The percentage of MB desorption was evaluated using the following equation:

$$
\mathrm{R}(\%)=\frac{m_{\text {des }}}{m_{a b s}} \times 100
$$

where $\mathrm{m}_{\text {des }}(\mathrm{mg} / \mathrm{g})$ and $\mathrm{m}_{\text {ads }}(\mathrm{mg} / \mathrm{g})$ are the amounts of desorbed and adsorbed MB, respectively (Azaman et al. 2018).

\section{RESULT AND DISCUSSION}

\section{RESPONSE SURFACE METHODOLOGY (RSM)}

A full design matrix for preparing AGSAC is presented in Table 2, together with the response values obtained from the experimental works. From the experimental data analysis, the range of $\mathrm{MB}$ removal was found to ranging from 58.64 to $94.11 \%$. For the removal of MB, y, a quadratic model was selected. The relationship between variables and response were represented in the final 
empirical models in terms of coded factor as shown in (11). The positive sign for all the terms presents a synergistic effect while the negative present an antagonistic effect (Junior et al. 2014; Zhou et al. 2020). The final empirical formula models for MB removal $\left(y_{1}\right)$ is expressed by (11): MB removal, y (\%):

$\mathrm{Y}=87.48+9.26 x_{1}+6.29 x_{2}-2.31 x_{1} x_{2}-14.47 x_{1}{ }^{2}-1.21 x_{2}{ }^{2}(11)$

TABLE 2. Experimental design matrix for the preparation of AGSAC

\begin{tabular}{llcl}
\hline & \multicolumn{2}{c}{ AGSAC preparation variable } & MB removal, (\%) \\
\cline { 2 - 3 } & Run & Radiation time,(min) & \\
\cline { 2 - 4 } 2 & 440 & 3 & 90.03 \\
3 & 616 & 4 & 86.49 \\
4 & 264 & 3 & 62.03 \\
5 & 264 & 4 & 68.12 \\
6 & 264 & 2 & 58.64 \\
7 & 440 & 3 & 90.34 \\
8 & 440 & 4 & 94.11 \\
9 & 616 & 2 & 86.23 \\
10 & 616 & 3 & 71.65 \\
11 & 440 & 3 & 89.93 \\
12 & 440 & 3 & 90.09 \\
13 & 440 & 2 & 66.09 \\
\hline & 440 & 3 & 89.32 \\
\hline
\end{tabular}

The coefficient of determination, $\mathrm{R}^{2}$ was used to determine the quality of the model. In this study, the $\mathrm{R}^{2}$ value for (4) was 0.979 , which can be considered as high as it is close to unity. This value indicates that $97.90 \%$ of the variation in the MB removal was coming from the experimental data. The model significance and adequacy was justified via Analysis of Variance (ANOVA). The ANOVA for the quadratic models for MB removal is presented in Table 3. Two parameters include Model F-value and Prob $>F$ was analyzed to judge the quality of the model developed. 
TABLE 3. Analysis of ANOVA for MB removal by AGSAC

\begin{tabular}{|c|c|c|c|c|c|}
\hline Source & Sum of squares & Degree of freedom & Mean square & F-value & Prob $>$ F \\
\hline Model & 1498.61 & 5 & 299.72 & 4.57 & 0.0358 \\
\hline$x_{1}$ & 514.86 & 1 & 514.86 & 7.85 & 0.0264 \\
\hline$x_{2}$ & 237.64 & 1 & 237.64 & 3.62 & 0.0987 \\
\hline$x_{1}^{2}$ & 578.62 & 1 & 578.62 & 8.82 & 0.0208 \\
\hline$x_{2}^{2}$ & 4.07 & 1 & 4.07 & 0.06 & 0.8104 \\
\hline$x_{1} x_{2}$ & 21.25 & 1 & 21.25 & 0.32 & 0.5869 \\
\hline
\end{tabular}

From Table 3, it shows that two factors were significant to the MB removal response. If the values of Prob $>\mathrm{F}$ are less than 0.05 , the terms of the model are described as significant as reflecting the error of less than $5 \%$. For example, the model F-value of 4.57 and Prob $>$ $F$ less than 0.05 indicate the model term was significant (Dixit \& Yadav 2019). In this scenario, $x_{1}$ and $x_{1}^{2}$ were remarkable model terms, meanwhile $x_{2}, x_{2}^{2}$ and $x_{1} x_{2}$ were unremarkable to the response. Based on F-value, MB removal by AGSAC was influenced primarily by quadratic of radiation power, $\mathrm{x}_{1}^{2}$ due to its highest $\mathrm{F}$-value of 8.82 , followed by radiation power, $\mathrm{x}_{1}$ with secondhighest F-value of 7.85 .

Figure 1 represents the three-dimensional (3D) response surfaces of the effect of microwave radiation power and activation time on MB removal by AGSAC. Based on Figure 1, MB removal increased as the power increased and slightly increased with activation time. The MB removal increases continuously as the radiation power increased until $440 \mathrm{~W}$. This is since higher radiation power causing more pores to be developed, thus increasing the adsorption capacity of AGSAC.

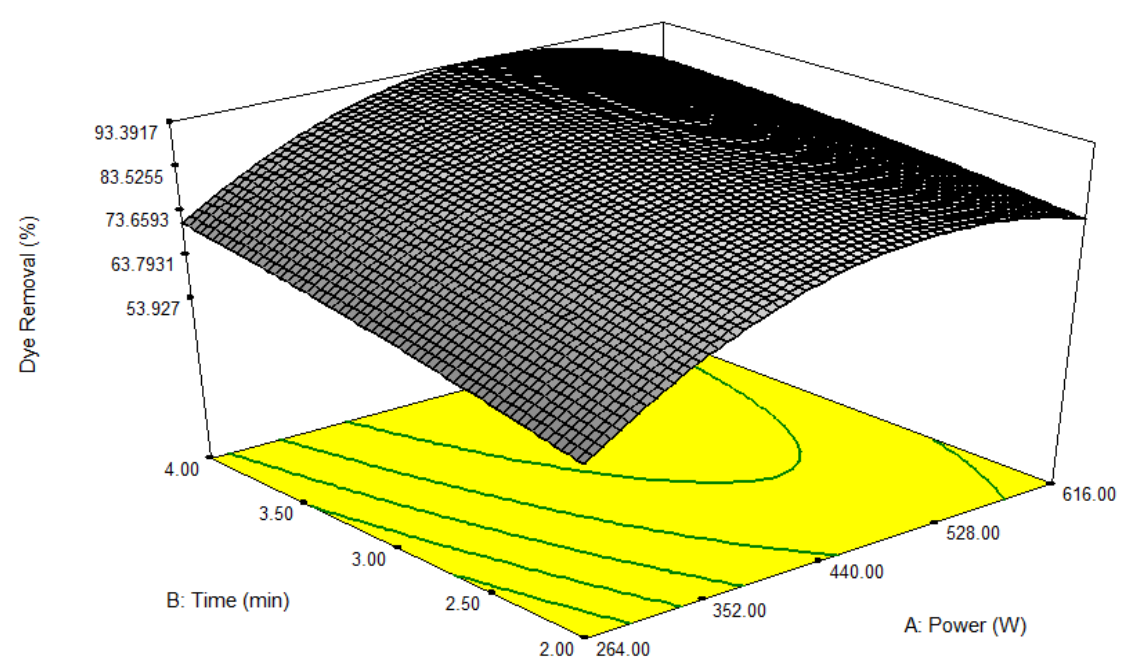

FIGURE 1. Three-dimensional response surface plot of MB removal of AGSAC 
As the radiation power continuously increased from 440 to $528 \mathrm{~W}$, the MB removal starts to decrease. Further increases in radiation power and activation time could induce over-abundance activation that affects some pores structures to disintegrate, leading towards decreased in surface area (Zhong et al. 2012). Apart from that, the shorter activation time and radiation power could not intensify the enlargement of porosity in the carbon sample (Chowdhury et al. 2012). Therefore, suitable radiation power was important to achieve a good quality of AGSAC, which could boost the adsorption capacity of MB dye removal.

\section{OPTIMIZATION OF OPERATING PARAMETERS}

The main aim of this study was to identify the optimum condition for AGSAC preparation to get high MB removal. Therefore, DOE was used to evaluate the optimal situation where the solution (MB percentage removal) was set at maximum value while the variables (radiation intensity and activation time) were set at a minimum. One solution was suggested by the DOE as the optimum condition for the preparation of AGSAC. Table 4 shows the model validation for MB removal. The optimum conditions were applied to prepare the optimized AGSAC.

TABLE 4. Model validation for MB removal

\begin{tabular}{|c|c|c|c|c|c|}
\hline \multirow{2}{*}{ Adsorbent } & \multirow{2}{*}{$\begin{array}{l}\text { Radiation power, } \\
\mathrm{x}_{1}(\mathrm{~W})\end{array}$} & \multirow{2}{*}{$\begin{array}{l}\text { Activation time, } \\
\mathrm{x}_{2}(\mathrm{~min})\end{array}$} & \multicolumn{3}{|c|}{ MB dye removal (\%) } \\
\hline & & & Predicted & Experimental & Error $(\%)$ \\
\hline AGSAC & 440 & 4 & 92.56 & 95.67 & 3.36 \\
\hline
\end{tabular}

Based on the result, the optimum radiation power and activation time was $440 \mathrm{~W}$ and $4 \mathrm{~min}$, respectively. This model's desirability was really strong, near to unity with 0.988 value. Furthermore, the predicted and experimental values of MB removal for this experiment were 92.56 and $95.67 \%$, respectively. The error for this model was relatively small with a value of $3.36 \%$. This indicates that the model was suitable and applicable for the preparation of AGSAC.

\section{CHARACTERIZATION OF DEVELOPED AGSAC \\ SURFACE AREA AND PORE CHARACTERISTICS}

According to the findings, the AGS has a small surface area and small pore volume. Before the activation process takes place, the value BET surface area for the precursor was $0.211 \mathrm{~m}^{2} / \mathrm{g}$, the mesopore surface area was $0.1331 \mathrm{~m}^{2} / \mathrm{g}$, the total pore volume was $0.0001 \mathrm{~cm}^{3} / \mathrm{g}$ and the average pore diameter was $3.06 \mathrm{~nm}$.
After the AGS undergoes the activation process, the BET surface area, mesopore surface area and total pore volume had a drastic increase as it is higher than the precursor. The value after the activation process for the BET surface area for the precursor was $172.19 \mathrm{~m}^{2} / \mathrm{g}$, the mesopore surface area was $103.32 \mathrm{~m}^{2} / \mathrm{g}$, and the total pore volume was $0.1077 \mathrm{~cm}^{3} / \mathrm{g}$. The average pore diameter was $2.05 \mathrm{~nm}$ which falls in the mesopores region, thus AGSAC is suitable to be used in dyes removal application in the first place.

The drastic change in surface area and pore characteristic of AGSAS is the proof of the effectiveness in activation step employed. During microwave irradiation for the physical activation process, $\mathrm{CO}_{2}$ molecules bombarded the skeleton of $\mathrm{AC}$, which intensify the development of pores network. This leads to an increment in surface area and improves the adsorption capacity of the sample (Ahmad \& Alrozi 2011). Furthermore, the vibration of the electron in the sample's structure 
at a rapid rate causing the temperature to increase and volatile matter to be released, thus making way for pores development to occur.

\section{SURFACE MORPHOLOGY OF SAMPLES}

Figure 2(a) and 2(b) presents the surface morphology of the AGS and AGSAC by SEM, respectively. Changes in the composition of the surface and pores were visible. In Figure 2(a), the surface of AGS was smooth with a very limited number of tiny pores detected. However, after the activation process, the morphology of AGSAC shows a significant amount of pore structure with a series of cavities with uniform distribution on the surface of AGSAC. During the activation process, cellulose was turned to porous solid carbon (Rashidi et al. 2012). The transformation of cellulose material into solid carbon had caused the enlarging of pores and the gaps between the crystallites. The physical activation using $\mathrm{CO}_{2}$ as a gasification agent had helped with altering the porosity and sample's surface texture.
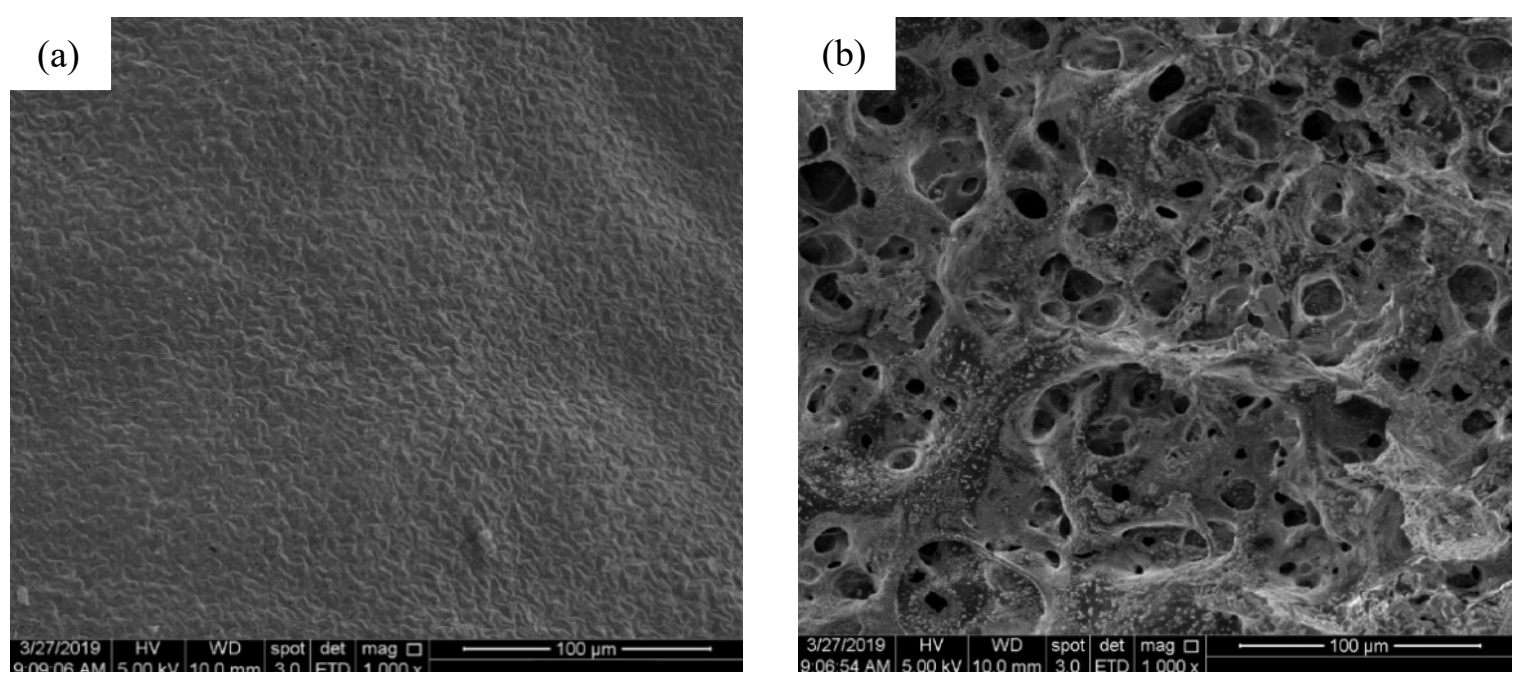

FIGURE 2. SEM micrographs of (a) AGS and (b) AGSAC (magnification 1000x)

\section{PROXIMATE ANALYSIS}

Based on the proximate analysis, it was found that AGS to be rich in moisture content, volatile matter, and amount of fixed carbon content which composes as the material that is a suitable precursor for the production of AC. The moisture content and volatility matter have been observed in AGS to be higher while in AGSAC to be lower. The moisture content and volatile matter of AGS decreased significantly from (18.73 to $11.59 \%$ ) and $(68.95$ to $36.83 \%)$, respectively, after the activation process. On the other hand, the amount of fixed carbon increased sharply from 8.64 to $47.63 \%$. This situation occurred associated due to the heat treatment during the activation process by the microwave irradiation. The organic compounds become unstable at high activation temperatures and break their bond and interaction while the volatile matter is released as a gas and liquid products are dispelled leaving the material with high carbon content (Arami-Niya et al. 2010).

\section{SURFACE CHEMISTRY}

FTIR spectra of AGSAC and AGSAC-MB (with loaded MB) were presented in Figure 3. As shown in Figure 3, FTIR 
spectra analysis showed that there are minimal differences in the spectral shape between the AGSAC and AGSACMB. After the adsorption of MB, several functional groups are shifted to different wavenumbers. The peak at $3420 \mathrm{~cm}^{-1}$ on AGSAC, which shifted to $3411 \mathrm{~cm}^{-1}$, represents the $\mathrm{O}-\mathrm{H}$ stretching vibration of the hydroxyl group ( $\mathrm{Li}$ et al. 2020). These variations may be due to the decomposition of organic content in AGSAC resulting in a reduction in peak value (Cheng et al. 2017). The bands observed at $2929 \mathrm{~cm}^{-1}$ on AGSAC, which shifted to 2923 $\mathrm{cm}^{-1}$ could be assigned to the $\mathrm{C}-\mathrm{H}$ stretching vibrations of methyl groups (Marrakchi et al. 2020). The peaks on AGSAC at 1612,1065 and $605 \mathrm{~cm}^{-1}$ were shifted to 1603 ,
1055 and $606 \mathrm{~cm}^{-1}$ which attribute to $\mathrm{C}=\mathrm{O}$ stretching vibrations, $\mathrm{C}-\mathrm{O}$ stretch inorganic carbonates, primary alcohols, and phenols, and out-of-plane bending mode of $\mathrm{C}-\mathrm{H}$ or $\mathrm{O}-\mathrm{H}$ groups, respectively. Possible $\pi-\pi$ interactions between aromatic groups in AGSAC surface and MB molecules has also led to the adsorption process (Liu et al. 2018; Üner et al. 2016).

From Figure 4, it can be seen that the $\mathrm{pH}$ of the point of zero charge $\left(\mathrm{pH}_{\mathrm{pzc}}\right)$ was 7.3 , which is close to 7. This findings indicates the neutral existence of the best AGSAC, which is compatible with the balance between the basic group material and the acidic surface functionalities.

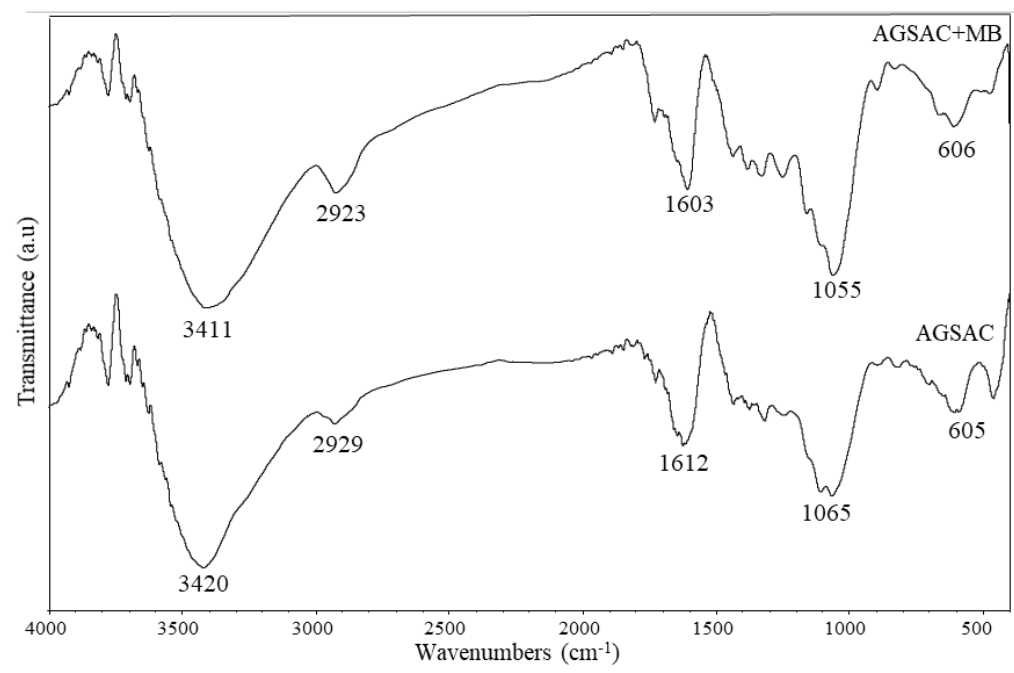

FIGURE 3. FTIR spectra of the AGSAC without and with loaded MB

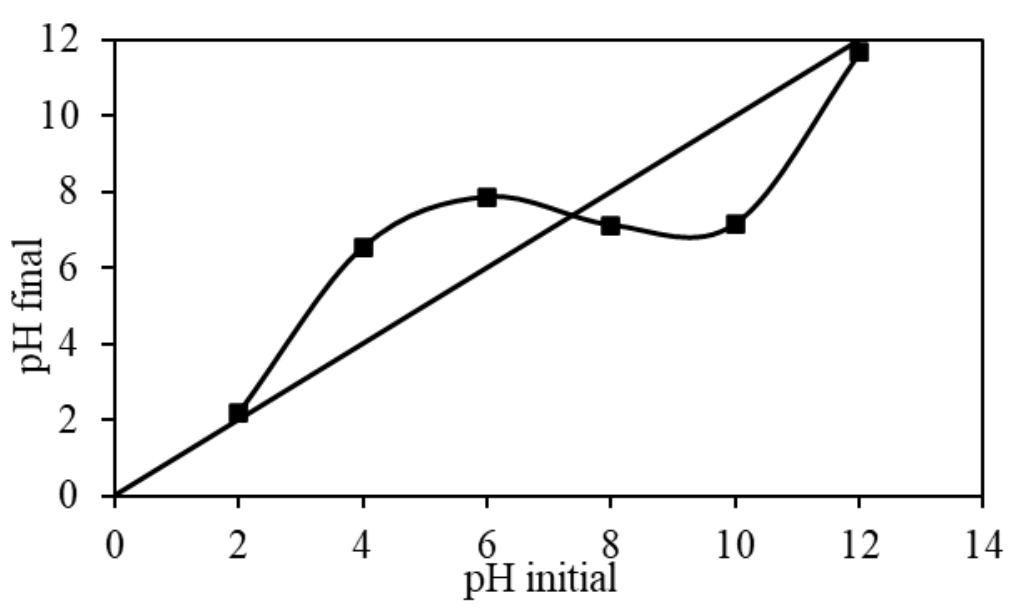

FIGURE 4. AGSAC's zero point charge $\left(\mathrm{pH}_{\mathrm{zpc}}\right)$ plot 
BATCH ADSORPTION STUDIES OF MB ON AGSAC EFFECT OF CONTACT TIME AND INITIAL CONCENTRATION ON DYE ADSORPTION

The adsorption studies were performed at $30{ }^{\circ} \mathrm{C}$ with distinct dye concentrations, from 25-300 mg/L. Figure 5(a) demonstrate the adsorption uptake by AGSAC and 5(b) MB percentage removal versus contact time, respectively, for different initial dye concentration at $30{ }^{\circ} \mathrm{C}$. From the graph, the number of dyes (MB) adsorbed onto AGSAC and the dye removal percentage increased as the increased initial dye concentration. Due to the availability of vacant surface sites for adsorption during the initial stage, the dye adsorption, $\mathrm{q}_{\mathrm{e}}$ to AGSAC, and MB removal increased over time. It can be seen at the first stage, adsorption uptake increased rapidly. This is due to the availability of the vacant site and a strong driving force for adsorption to take place ( $\mathrm{Li}$ et al. 2009). After two hours, the values of $\mathrm{q}_{\mathrm{e}}$ increased gradually as the remaining active site started to eventually and hard to be dominated due to the repulsive force between solute molecules in both phases (Hameed \& El-Khaiary 2008). As can be observed, after reaching $20 \mathrm{~h}$, the adsorption started to reach equilibrium. This shows that the number of dyes adsorbed starts to remain constant towards the end of the adsorption process.

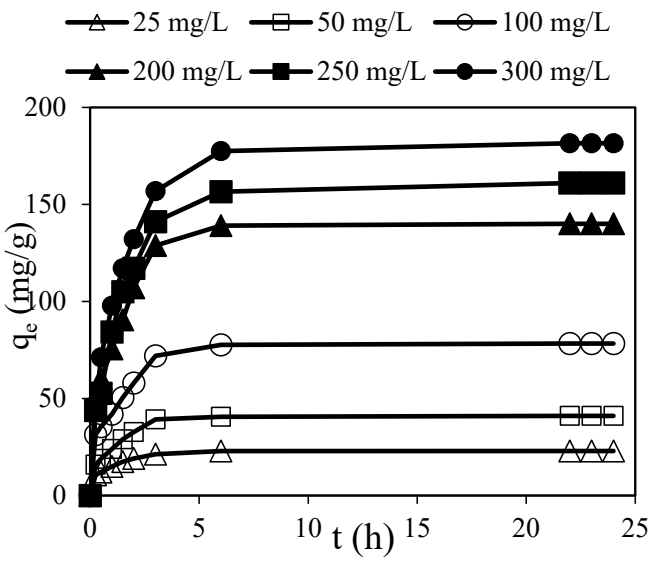

(a)

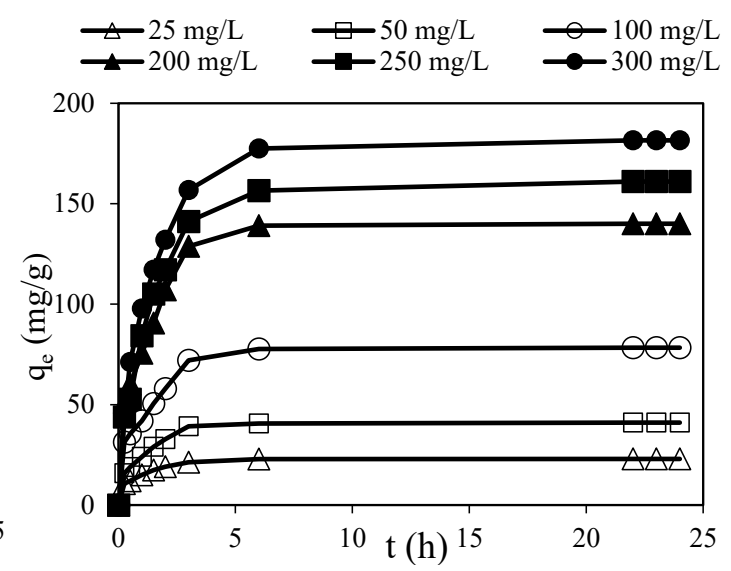

(b)

FIGURE 5. (a)MB adsorption uptake and (b) MB percentage removal versus adsorption time at different initial dyes concentration at $30^{\circ} \mathrm{C}$

Table 5 presents the removal of MB by AGSAC. The percentage of MB removal was the highest (91.98\%) and lowest $(60.51 \%)$ at a dye concentration of 25 and 300 $\mathrm{mg} / \mathrm{L}$, respectively. At lower dye concentration, the ratio of the number of dyes to available sites for adsorption to take place is low. Therefore, less competition occurs among the dyes molecules in occupying the adsorption sites. As the result, percentage removal becomes higher. As the dyes concentration increased, the ratio of the number of dyes to available sites increased as well. This caused the competition between dyes molecules to be adsorbed by AGSAC became tougher, thus resulted in lower MB percentage removal. 
TABLE 5. Percentage of removal of MB on AGSAC at $30^{\circ} \mathrm{C}$

\begin{tabular}{|c|c|c|c|c|c|c|}
\hline \multirow[t]{2}{*}{ Dye } & \multicolumn{6}{|c|}{ Removal (\%) } \\
\hline & $25 \mathrm{mg} / \mathrm{L}$ & $50 \mathrm{mg} / \mathrm{L}$ & $100 \mathrm{mg} / \mathrm{L}$ & $200 \mathrm{mg} / \mathrm{L}$ & $250 \mathrm{mg} / \mathrm{L}$ & $300 \mathrm{mg} / \mathrm{L}$ \\
\hline MB & 91.98 & 82.08 & 78.34 & 70.02 & 64.41 & 60.51 \\
\hline
\end{tabular}

\section{ADSORPTION ISOTHERM}

Three isotherm models were studied in this experiment using Langmuir, Freundlich, and Temkin isotherms. Langmuir model was first developed to express the gassolid phase adsorption and now, this model is essential to quantify the adsorptive capacity of numerous adsorbents (Elmorsi 2011). Langmuir isotherm describes the monolayer surface coverage of adsorbate onto adsorbent at dynamic equilibrium where relative rate of adsorption and desorption are equal. This model predicts that adsorption is proportional to the fraction of the adsorbent that is open whereas desorption is proportional to the fraction of adsorbent surface that is covered (Günay et al. 2007). Freundlich model describes adsorption process that took place on heterogenous surface (Nimibofa et al. 2015a). This model also provides parameters that defines the surface heterogeneity together with exponential distribution of active sites and their respective energies (Nimibofa et al. 2015b). Last but not least, Temkin model considers the indirect interaction between adsorbates and adsorbents in affecting the adsorption process. This model also assumed that the heat of adsorption of all molecules in the layer decreases linearly with the increasing of surface coverage (Ringot et al. 2007). The linearized plots for the three models are shown in Figure 6 at the MB solution temperature of $30{ }^{\circ} \mathrm{C}$. Table 6 lists the summary values of isothermal constants calculated from plots like $\mathrm{R}^{2}$, adsorption power $\left(\mathrm{q}_{\mathrm{e}}\right)$, and other constant parameters at $30{ }^{\circ} \mathrm{C}$. All isotherm models used were represented by relative certain constants that characterized the surface properties and the adsorption capability of this material (Aljeboree et al. 2017). Overall, the best model is chosen based on the fitted equilibrium data in the following sequence: Freundlich $>$ Langmuir $>$ Temkin. The value of $\mathrm{R}^{2}$ is chosen on the value that nearest to unity. Freundlich isotherm model was best fitted with the highest correlation coefficient, $\mathrm{R}^{2}$ at 0.99 , as shown in Table 6 . This verified that a multilayer's adsorption of MB molecules onto heterogeneous surfaces of AGSAC was taken place through active sites with different energies (Silva et al. 2018).

Next, the $\mathrm{K}_{\mathrm{F}}$ value, one of the Freundlich constant that is used as a relative measure of adsorption uptake, which $\mathrm{K}_{\mathrm{F}}$ reaches the values of $\mathrm{q}_{\mathrm{m}}$ when the equilibrium concentration $\mathrm{C}_{\mathrm{e}}$ approaches to unity, thus can be considered as an indicative parameter of the adsorption strength. Meanwhile, the value of $\mathrm{N}_{\mathrm{F}}>1$ suggested that MB dye was favorably adsorbed by AGSAC. Furthermore, Langmuir isothermic fundamental function expressed in separation factor $R_{L}$ can be used to evaluate the favourability of an adsorption process. The $\mathrm{R}_{\mathrm{L}}$ shows if the adsorption mechanism is unfavourable $\left(R_{L}>1\right)$, linear $\left(R_{L}=1\right)$, favourable $\left(0<R_{L}<1\right)$ or irreversible $\left(R_{L}=0\right)$. The calculated $R_{L}$ value for this research was in the range of 0 to 0.6 . This proves that adsorption of $\mathrm{MB}$ dye onto AGSAC was favorable at the condition being studied. $R_{L}$ value decrease with an increase in initial concentration from 25 to $300 \mathrm{mg} / \mathrm{L}$ indicates that adsorption was more desirable at higher dye concentration. Higher MB initial concentration showed that stronger mass transfer driving force needed to overcome adsorption resistance, therefore increased the likeliness of the adsorption process to perform. Table 7 shows the adsorption capacity comparison between AGSAC and precursors from other works. Based on this comparison, it can be said that AGSAC's adsorption performance is relatively moderate. 

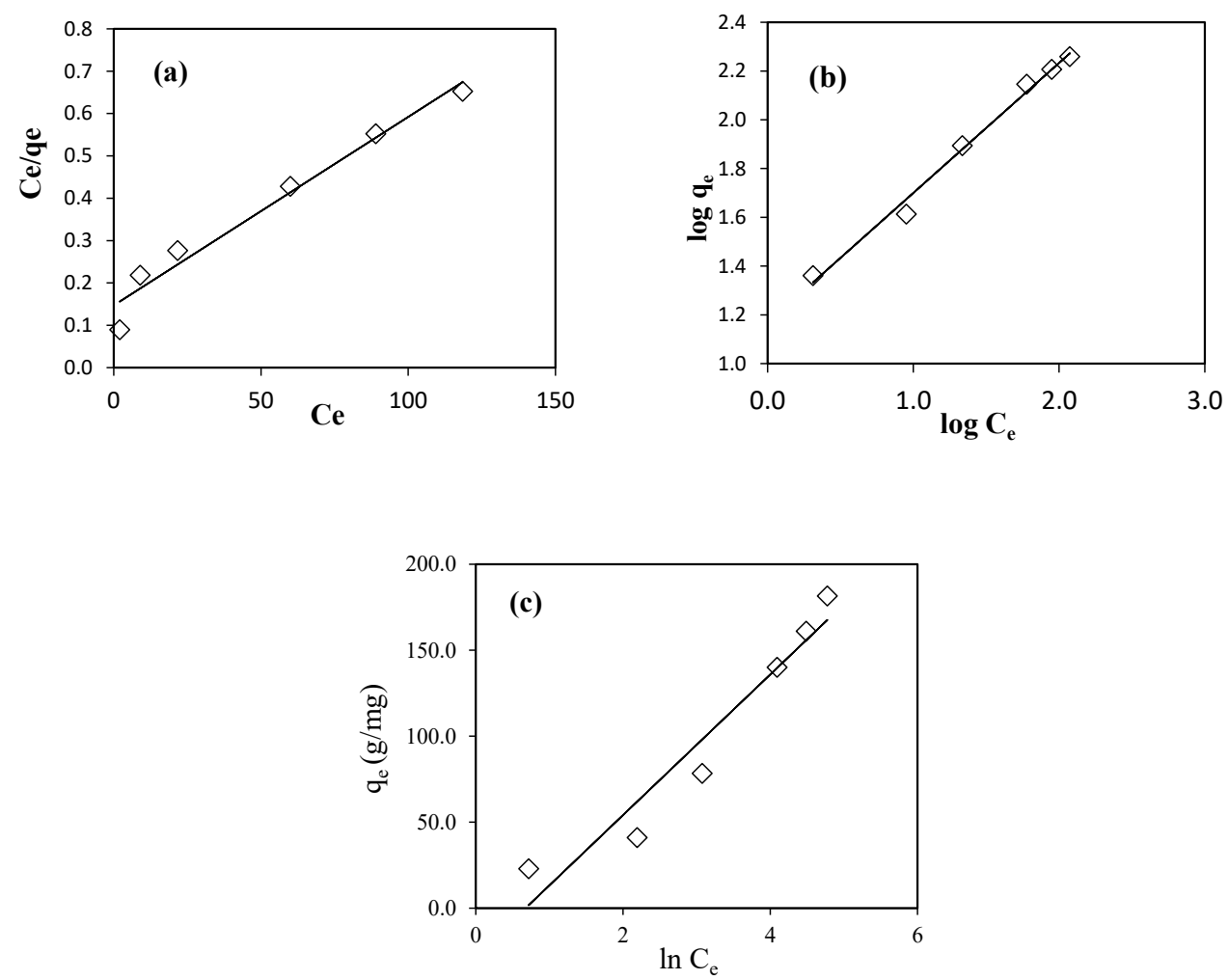

FIGURE 6. Fitting of experimental data in different isotherms models (a) Langmuir (b) Freundlich and (c) Temkin

TABLE 6. Adsorption isotherm parameters of MB dye adsorption at $30{ }^{\circ} \mathrm{C}$

\begin{tabular}{ccccccccccc}
\hline & \multicolumn{3}{c}{ Langmuir } & \multicolumn{3}{c}{ Freundlich } & \multicolumn{3}{c}{ Temkin } \\
\cline { 2 - 11 } & $\mathrm{q}_{\mathrm{m}}(\mathrm{mg} / \mathrm{g})$ & $\mathrm{K}_{\mathrm{L}}(\mathrm{L} / \mathrm{mg})$ & $\mathrm{R}^{2}$ & $\mathrm{~K}_{\mathrm{F}}$ & $\mathrm{n}$ & $\mathrm{R}^{2}$ & $\mathrm{~B}_{\mathrm{T}}$ & $\mathrm{N}_{\mathrm{T}}$ & $\mathrm{R}^{2}$ \\
\hline 30 & 222.22 & 0.03 & 0.97 & 14.69 & 1.88 & 0.99 & 40.97 & 0.51 & 0.93 \\
\hline
\end{tabular}

TABLE 7. Comparison of AGSAC's adsorption capacity with other adsorbents

\begin{tabular}{lccc}
\hline \multicolumn{1}{c}{ Precursor } & Adsorbates & $\begin{array}{c}\text { Adsorption capacity } \\
(\mathrm{mg} / \mathrm{g})\end{array}$ & References \\
\hline Alpinia galanga stem & MB dye & 222.22 & This study \\
Meranti wood sawdust & MB dye & 344.83 & (Ahmad et al. 2020) \\
Durian peel & Remazol brilliant blue R dye & 125.00 & (Yusop et al. 2020) \\
Acacia wood sawdust & Remazol brilliant blue R dye & 263.16 & (Yusop et al. 2017) \\
Coconut shell & MB dye & 166.70 & (Widiyastuti et al. 2020) \\
Oil palm empty fruit bunch & Cibacron blue 3G-A & 393.67 & (Jabar \& Odusote 2020) \\
Indian almond shell & Azure A dye & 114.20 & (Sivakumar et al. 2019) \\
Ground nut shell & Azure A dye & 106.80 & 59.05 \\
Areca nut shell & Azure A dye &
\end{tabular}




\section{ADSORPTION KINETIC STUDIES}

The adsorption kinetic studies are important to provide understanding about the mechanism of adsorption process and the potential rate-controlling step (Sartape et al. 2010). The adsorption rate is calculated using kinetic models which were pseudo-first order and pseudo-second order to analyze the MB adsorption process on prepared AGSAC. The linearized plot of pseudo-first order and pseudo-second order at $30^{\circ} \mathrm{C}$ are present in Figure 7. Table 8 summarized the parameters specified for these two models. The experimental data in Table 8 showed that MB adsorption was found to fit the pseudo-second order kinetic model better compared to pseudo-first order based on $\mathrm{R}^{2}$. Similar result was obtained in the study MB dye removal by Mahogany fruit shell where pseudo-second order shows a better fit compared to pseudo-first order (Sartape et al. 2015). It is observed that the values of $\mathrm{k}_{1}$ and $\mathrm{k}_{2}$ decreased with an increase in initial concentration. At a higher concentration of $\mathrm{MB}$, the ratio of adsorbate molecules to the adsorbent surface available was high, which resulted in slower adsorption and a lower rate constant. Besides, the $\mathrm{q}_{\mathrm{e}}$ value of the pseudo-second order was much closer to the experimental $\mathrm{q}_{\mathrm{e}}$, values as compared to the pseudofirst order model. Therefore, it is proved that MB removal by AGSAC followed pseudo-second order kinetic models.
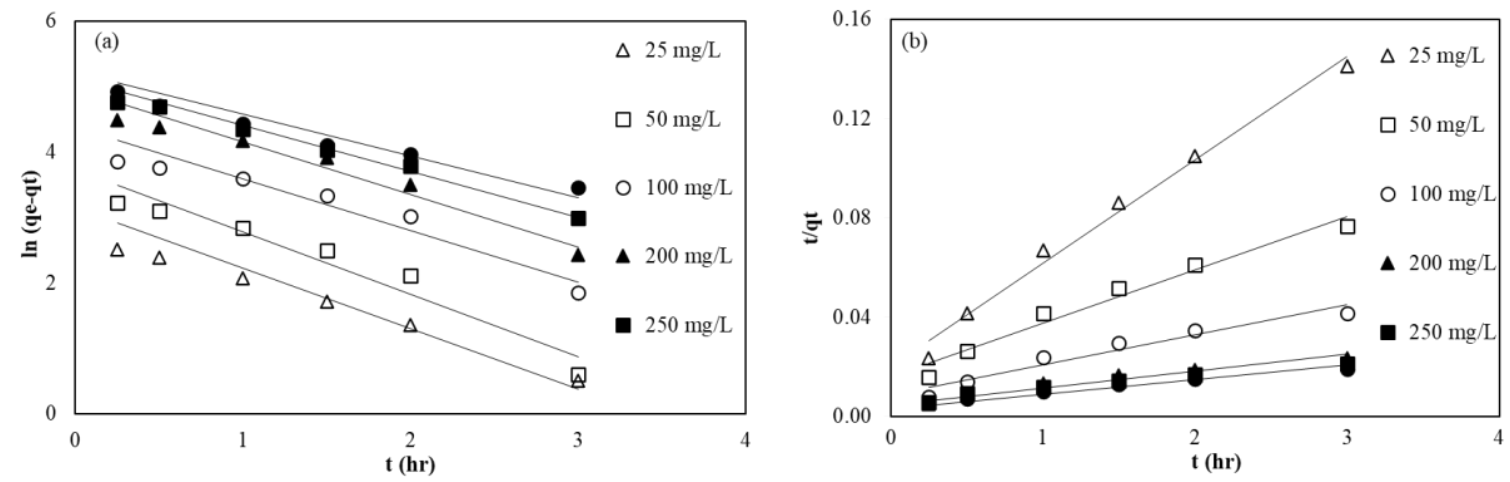

FIGURE 7. Linearized plots of (a) pseudo-first order and (b) pseudo-second order for adsorption on AGSAC at $30^{\circ} \mathrm{C}$

TABLE 8 . Kinetic parameters of MB dye adsorption at $30^{\circ} \mathrm{C}$

\begin{tabular}{lcccccccc}
\hline & Experiment data & \multicolumn{3}{c}{ Pseudo-first order } & \multicolumn{3}{c}{ Pseudo-second order } \\
\cline { 2 - 8 } & $\begin{array}{c}\mathrm{q}_{\mathrm{e}} \\
(\mathrm{mg} / \mathrm{g})\end{array}$ & $\begin{array}{c}\mathrm{k}_{1} \\
\left(\mathrm{hr}^{-1}\right)\end{array}$ & $\mathrm{q}_{\mathrm{e}}(\mathrm{mg} / \mathrm{g})$ & $\mathrm{R}^{2}$ & $\mathrm{k} \mathrm{k}_{2}(\mathrm{~g} / \mathrm{mg} \cdot \mathrm{hr})$ & $\mathrm{q}_{\mathrm{e}}(\mathrm{mg} / \mathrm{g})$ & $\mathrm{R}^{2}$ \\
\hline 25 & 22.949 & 1.095 & 32.95 & 0.89 & 0.109 & 23.15 & 0.99 \\
50 & 41.041 & 1.019 & 47.47 & 0.92 & 0.041 & 44.48 & 0.97 \\
100 & 78.335 & 0.798 & 79.60 & 0.91 & 0.022 & 78.74 & 0.97 \\
200 & 140.039 & 0.754 & 147.08 & 0.95 & 0.011 & 144.93 & 0.95 \\
250 & 161.035 & 0.752 & 181.45 & 0.89 & 0.005 & 169.49 & 0.97 \\
300 & 181.539 & 0.727 & 219.20 & 0.89 & 0.001 & 204.08 & 0.99
\end{tabular}




\section{ADSORPTION MECHANISM}

The kinetic mechanisms were further analyzed using the MB dye adsorption intraparticle diffusion model on the AGSAC. The intraparticle diffusion plots for removal of
MB dye at $30{ }^{\circ} \mathrm{C}$ are shown in Figure 8 and the mechanism has been analyzed by fitting the data into an intraparticle diffusion plot.

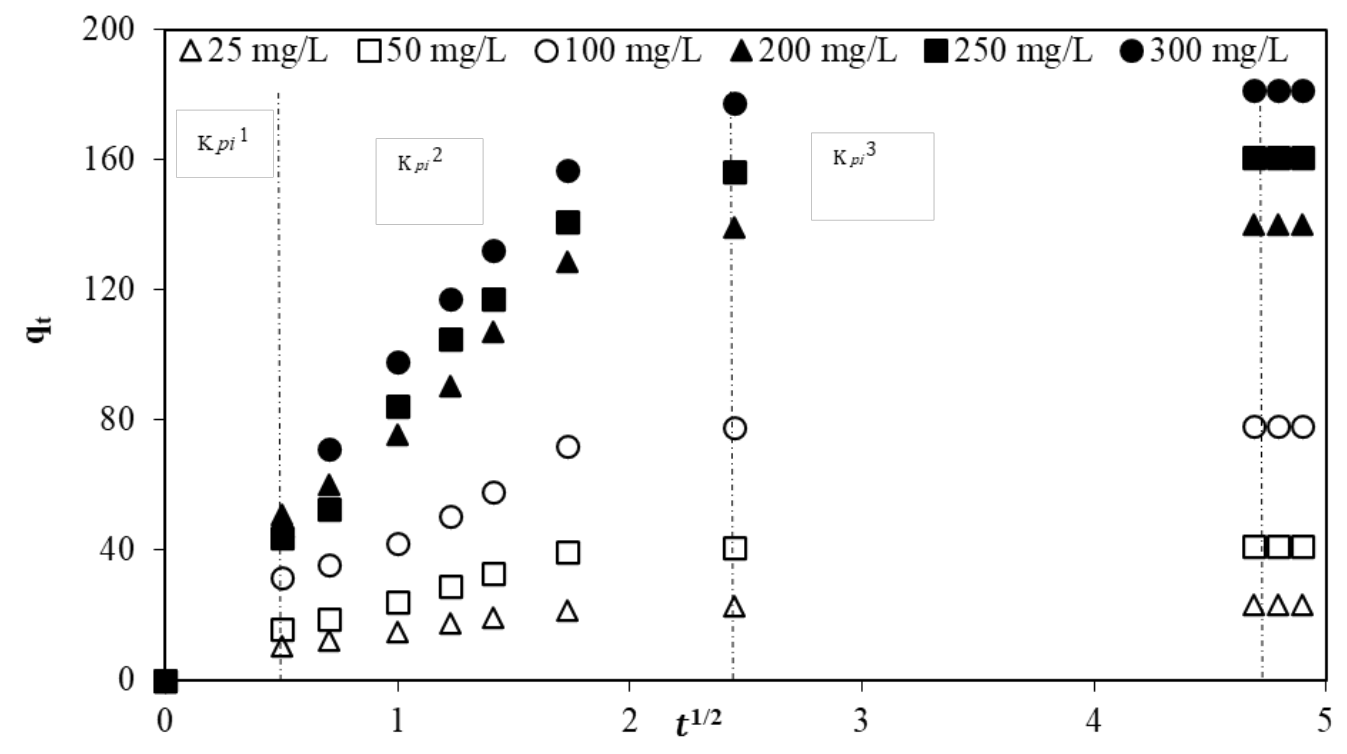

FIGURE 8. Plots of intraparticle diffusion model for removal of MB on AGSAC at $30^{\circ} \mathrm{C}$

From Figure 8, we can see that the intraparticle diffusion was divided into three different regions. The three different regions begin with film diffusion followed by particle diffusion and adsorption of the adsorbate molecules on the interior of the porous adsorbent (Chingombe et al. 2006). Firstly, within 0.5 h, the sharper region was easily adsorbed due to the heavy electrostatic attraction between the dye and the external surface of the adsorbent. The second stage was from 0.5 to $2.5 \mathrm{~h}$, gradual adsorption occurs at this stage. This indicates that the intraparticle diffusion of dye molecules through adsorbent pores is a rate-controlling step (Ahmad et al. 2009). The third stage was from 2.5 to $24 \mathrm{~h}$ where the trend tends to become constant and equilibrium. This region is the final stage which is the equilibrium region in which the intraparticle is slowing down because of extremely low adsorbed concentrations in the solutions.

\section{DESORPTION AND REUSABILITY STUDIES}

The main objective for conducting desorption studies is to analyse the recovery of adsorbate, subsequent regeneration, and reuse of adsorbent after the adsorption process. Figure 9 shows the reusability of AGSCAC after five consecutive cycles of adsorption/desorption. The MB adsorption efficiency had decreased from $76 \%$ at the first cycle to $35 \%$ at the end of the fifth cycle. This might be due to the decreasing MB uptake by the AGSAC, which indicated a loss in regeneration efficiency for continuous regeneration cycles. The ability to withstand five consecutive adsorption/desorption cycles has shown that 


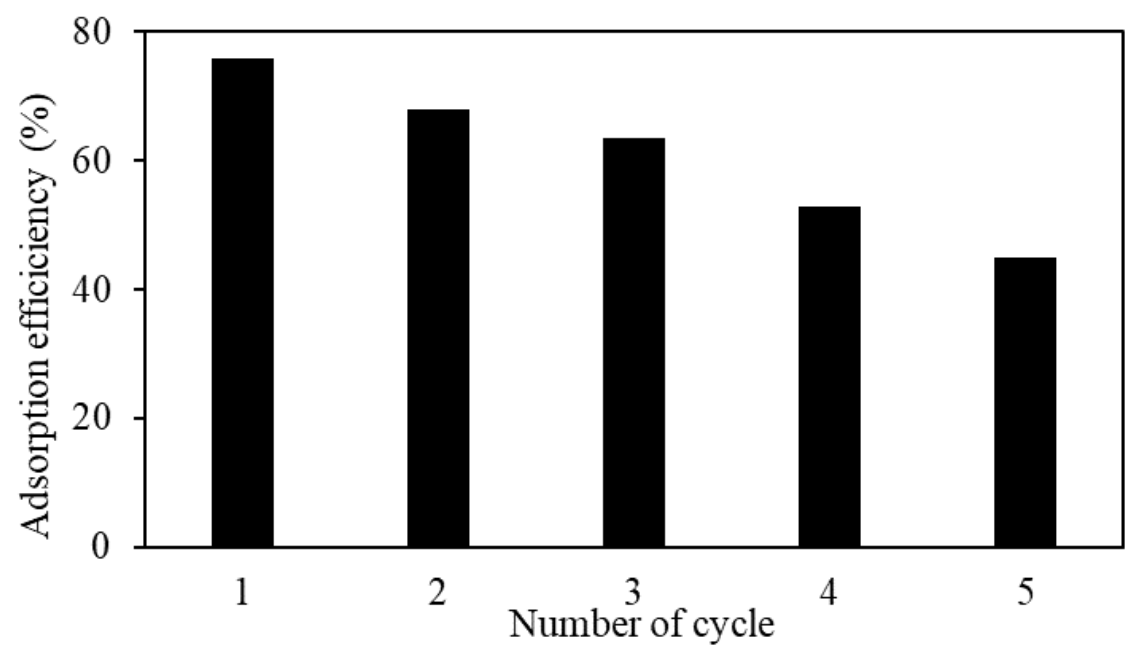

FIGURE 9. Adsorption/desorption cycle of used AGSAC

AGSCAC possesses a successful adsorbents reusability characteristic, one of the most critical requirements in the design of economical adsorption processes.

\section{CONCLUSION}

Single-step microwave irradiation together with $\mathrm{CO}_{2}$ gasification was succeeded in producing AGSAC with a monolayer adsorption capacity of $222.22 \mathrm{mg} / \mathrm{g}$. RSM with the FCD method showed that the optimum preparation conditions of AGSAC to be $440 \mathrm{~W}$ and $4 \mathrm{~min}$ for radiation power and activation time, respectively. These optimum conditions contributed to $95.67 \%$ of MB removal. The optimized AGSAC has a Bruneaur-Emmet-Teller (BET) surface area of $172.19 \mathrm{~m}^{2} / \mathrm{g}$, mesopore surface area of $103.32 \mathrm{~m}^{2} / \mathrm{g}$, and total pore volume of $0.1077 \mathrm{~cm}^{3} / \mathrm{g}$. MB adsorption onto AGSAC was best described by Freundlich and pseudo-second order for isotherm and kinetic studies, respectively. This study proved that AGSAC can be a good adsorbent.

\section{ACKNOWLEDGEMENTS}

The authors would like to acknowledge Universiti Sains Malaysia for providing research grant (304/ PJKIMIA/6050434/I136) and scholarships through USM Fellowship Program to Master of Science candidate, Nur Azian Ahammad.

\section{REFERENCES}

Ahmad, A., Rafatullah, M., Sulaiman, O., Ibrahim, M. \& Hashim, R. 2009. Scavenging behaviour of meranti sawdust in the removal of methylene blue from aqueous solution. Journal of Hazardous Materials 170(1): 357-365.

Ahmad, M.A. \& Alrozi, R. 2011. Optimization of rambutan peel based activated carbon preparation conditions for Remazol Brilliant Blue R removal. Chemical Engineering Journal 168(1): 280-285.

Ahmad, M.A., Yusop, M.F.M. \& Tan, S.H. 2020. Activated carbon from meranti wood sawdust waste prepared by microwave heating for dye removal. In Advances in Waste Processing Technology, edited by Yaser, A.Z. Singapore: Springer. pp. 61-87.

Ajduković, M., Stojadinović, S., Marinović, S., MilutinovićNikolić, A., Dojčinović, B. \& Banković, P. 2020. Activation of Oxone ${ }^{\circledR}$ with plasma deposited mixed cobalt and alumina oxide for the dye degradation. Applied Surface Science 503: 144144.

Alhooshani, K.R. 2019. Adsorption of chlorinated organic compounds from water with cerium oxide-activated carbon composite. Arabian Journal of Chemistry 12(8): $2585-$ 2596.

Aljeboree, A.M., Alshirifi, A.N. \& Alkaim, A.F. 2017. Kinetics and equilibrium study for the adsorption of textile dyes on coconut shell activated carbon. Arabian Journal of Chemistry 10: S3381-S3393.

Amézquita-Marroquín, C.P., Torres-Lozada, P., Giraldo, L., Húmpola, P.D., Rivero, E., Poon, P.S., Matos, J. \& Moreno- 
Piraján, J.C. 2020. Sustainable production of nanoporous carbons: Kinetics and equilibrium studies in the removal of atrazine. Journal of Colloid and Interface Science 562: 252-267.

Arami-Niya, A., Daud, W.M.A.W. \& Mjalli, F.S. 2010. Using granular activated carbon prepared from oil palm shell by $\mathrm{ZnCl}_{2}$ and physical activation for methane adsorption. Journal of Analytical and Applied Pyrolysis 89(2): 197203.

Ayawei, N., Angaye, S.S., Wankasi, D. \& Dikio, E.D. 2015. Synthesis, characterization and application of $\mathrm{Mg} / \mathrm{Al}$ layered double hydroxide for the degradation of congo red in aqueous solution. Open Journal of Physical Chemistry 5(3): 56

Azaman, S.H., Afandi, A., Hameed, B.H. \& Din, A.M. 2018. Removal of malachite green from aqueous phase using coconut shell activated carbon: Adsorption, desorption, and reusability studies. Journal of Applied Science and Engineering 21(3): 317-330.

Barghi, S.H., Tsotsis, T.T. \& Sahimi, M. 2014. Chemisorption, physisorption and hysteresis during hydrogen storage in carbon nanotubes. International Journal of Hydrogen Energy 39(3): 1390-1397.

Basu, S., Ghosh, G. \& Saha, S. 2018. Adsorption characteristics of phosphoric acid induced activation of bio-carbon: Equilibrium, kinetics, thermodynamics and batch adsorber design. Process Safety and Environmental Protection 117: 125-142.

Belayachi, H., Bestani, B., Benderdouche, N. \& Belhakem, M. 2019. The use of $\mathrm{TiO}_{2}$ immobilized into grape marcbased activated carbon for RB-5 Azo dye photocatalytic degradation. Arabian Journal of Chemistry 12(8): 30183027.

Bhat, S.A., Zafar, F., Mirza, A.U., Mondal, A.H., Kareem, A., Haq, Q.M.R. \& Nishat, N. 2020. NiO nanoparticle dopedPVA-MF polymer nanocomposites: Preparation, congo red dye adsorption and antibacterial activity. Arabian Journal of Chemistry 13(6): 5724-5739.

Bojić, D., Momčilović, M., Milenković, D., Mitrović, J., Banković, P., Velinov, N. \& Nikolić, G. 2017. Characterization of a low cost Lagenaria vulgaris based carbon for ranitidine removal from aqueous solutions. Arabian Journal of Chemistry 10(7): 956-964.

Cheng, S., Zhang, L., Xia, H., Peng, J., Shu, J., Li, C., Jiang, X. \& Zhang, Q. 2017. Adsorption behavior of methylene blue onto waste-derived adsorbent and exhaust gases recycling. RSC Advances 7(44): 27331-27341.

Chingombe, P., Saha, B. \& Wakeman, R.J. 2006. Sorption of atrazine on conventional and surface modified activated carbons. Journal of Colloid and Interface Science 302(2): 408-416.

Chowdhury, Z., Mohd, S., Zain, S., Rashid, A., Arami Niya, A. \& Khalisanni, K. 2012. Process variables optimization for preparation and characterization of novel adsorbent from lignocellulosic waste. Bioresources 7(3): 3732-3754.
Damasceno, B.S., da Silva, A.F.V. \& de Araújo, A.C.V. 2020. Dye adsorption onto magnetic and superparamagnetic $\mathrm{Fe}_{3} \mathrm{O}_{4}$ nanoparticles: A detailed comparative study. Journal of Environmental Chemical Engineering 8(5): 103994.

Davarnejad, R., Afshar, S. \& Etehadfar, P. 2020. Activated carbon blended with grape stalks powder: Properties modification and its application in a dye adsorption. Arabian Journal of Chemistry 13(5): 5463-5473.

Dixit, S. \& Yadav, V.L. 2019. Optimization of polyethylene/ polypropylene/alkali modified wheat straw composites for packaging application using RSM. Journal of Cleaner Production 240: 118228.

Ebrahiem, E.E., Al-Maghrabi, M.N. \& Mobarki, A.R. 2017. Removal of organic pollutants from industrial wastewater by applying photo-Fenton oxidation technology. Arabian Journal of Chemistry 10: S1674-S1679.

Elmorsi, T. 2011. Equilibrium isotherms and kinetic studies of removal of methylene nlue dye by adsorption onto miswak leaves as a natural adsorbent. Journal of Environmental Protection 2(6): 817.

Feng, C., Ren, P., Huo, M., Dai, Z., Liang, D., Jin, Y. \& Ren, F. 2020. Facile synthesis of trimethylammonium grafted cellulose foams with high capacity for selective adsorption of anionic dyes from water. Carbohydrate Polymers 241: 116369.

Freundlich, H. 1907. Über die adsorption in lösungen. Zeitschrift für Physikalische Chemie 57U(1): 385-470.

Gonzalez, J.M., Murphy, L.R., Penn, C.J., Boddu, V.M. \& Sanders, L.L. 2020. Atrazine removal from water by activated charcoal cloths. International Soil and Water Conservation Research 8(2): 205-212.

Guedidi, H., Lakehal, I., Reinert, L., Lévêque, J.M., Bellakhal, N. \& Duclaux, L. 2020. Removal of ionic liquids and ibuprofen by adsorption on a microporous activated carbon: Kinetics, isotherms, and pore sites. Arabian Journal of Chemistry 13(1): 258-270.

Guillossou, R., Le Roux, J., Mailler, R., Morlay, C., Vulliet, E., Nauleau, F., Rocher, V. \& Gasperi, J. 2020. Influence of the properties of 7 micro-grain activated carbons on organic micropollutants removal from wastewater effluent. Chemosphere 243: 125306.

Günay, A., Arslankaya, E. \& Tosun, İ. 2007. Lead removal from aqueous solution by natural and pretreated clinoptilolite: Adsorption equilibrium and kinetics. Journal of Hazardous Materials 146(1): 362-371.

Guo, Z., Kang, Y., Hu, Z., Liang, S., Xie, H., Ngo, H.H. \& Zhang, J. 2020. Removal pathways of benzofluoranthene in a constructed wetland amended with metallic ions embedded carbon. Bioresource Technology 311: 123481.

Habeeb, O.A., Kanthasamy, R., Saber, S.E.M. \& Olalere, O.A. 2020. Characterization of agriculture wastes based activated carbon for removal of hydrogen sulfide from petroleum refinery waste water. Materials Today: Proceedings 20: 588-594. 
Hameed, B.H. \& El-Khaiary, M.I. 2008. Equilibrium, kinetics and mechanism of malachite green adsorption on activated carbon prepared from bamboo by $\mathrm{K}_{2} \mathrm{CO}_{3}$ activation and subsequent gasification with $\mathrm{CO}_{2}$. Journal of Hazardous Materials 157(2): 344-351.

Hameed, K.S., Muthirulan, P. \& Sundaram, M.M. 2017. Adsorption of chromotrope dye onto activated carbons obtained from the seeds of various plants: Equilibrium and kinetics studies. Arabian Journal of Chemistry 10: S2225-S2233.

Ho, Y.S. \& McKay, G. 1999. Pseudo-second order model for sorption processes. Process Biochemistry 34(5): 451-465.

Ilnicka, A., Kamedulski, P., Aly, H.M. \& Lukaszewicz, J.P. 2020. Manufacture of activated carbons using Egyptian wood resources and its application in oligothiophene dye adsorption. Arabian Journal of Chemistry 13(5): 5284-5291.

Isawi, H. 2020. Using zeolite/polyvinyl alcohol/sodium alginate nanocomposite beads for removal of some heavy metals from wastewater. Arabian Journal of Chemistry 13(6): 5691-5716.

Jabar, J.M. \& Odusote, Y.A. 2020. Removal of cibacron blue $3 \mathrm{G}-\mathrm{A}(\mathrm{CB})$ dye from aqueous solution using chemophysically activated biochar from oil palm empty fruit bunch fiber. Arabian Journal of Chemistry 13(5): 5417-5429.

Joseph, J., Radhakrishnan, R.C., Johnson, J.K., Joy, S.P. \& Thomas, J. 2020. Ion-exchange mediated removal of cationic dye-stuffs from water using ammonium phosphomolybdate. Materials Chemistry and Physics 242: 122488.

Jović, B., Kordić, B., Miškov, V., Tričković, J., Kovačević, M. \& Petrović, S. 2020. Amides as a model system of low molar mass algal organic matter. Influence on the adsorption of p-nitrophenol on activated carbon. Arabian Journal of Chemistry 13(1): 59-66.

Junior, O.P., Cazetta, A.L., Gomes, R.C., Barizão, É.O., Souza, I.P., Martins, A.C., Asefa, T. \& Almeida, V.C. 2014. Synthesis of $\mathrm{ZnCl}_{2}$-activated carbon from macadamia nut endocarp (Macadamia integrifolia) by microwave-assisted pyrolysis: Optimization using RSM and methylene blue adsorption. Journal of Analytical and Applied Pyrolysis 105: 166-176.

Kaminski, P. 2020. The application of FTIR in situ spectroscopy combined with methanol adsorption to the study of mesoporous sieve SBA-15 with cerium-zirconium oxides modified with gold and copper species. Arabian Journal of Chemistry 13(1): 851-862.

Kariim, I., Abdulkareem, A.S. \& Abubakre, O.K. 2020. Development and characterization of MWCNTs from activated carbon as adsorbent for metronidazole and levofloxacin sorption from pharmaceutical wastewater: Kinetics, isotherms and thermodynamic studies. Scientific African 7: e00242.

Köpping, I., McArdell, C.S., Borowska, E., Böhler, M.A. \& Udert, K.M. 2020. Removal of pharmaceuticals from nitrified urine by adsorption on granular activated carbon. Water Research X 9: 100057.

Kumar, J.A., Amarnath, D.J., Sathish, S., Jabasingh, S.A., Saravanan, A., Hemavathy, R.V., Anand, K.V. \& Yaashikaa, P.R. 2019. Enhanced PAHs removal using pyrolysis-assisted potassium hydroxide induced palm shell activated carbon: Batch and column investigation. Journal of Molecular Liquids 279: 77-87.

Kumar, V. 2019. Adsorption kinetics and isotherms for the removal of rhodamine $\mathrm{B}$ dye and $\mathrm{Pb}^{+2}$ ions from aqueous solutions by a hybrid ion-exchanger. Arabian Journal of Chemistry 12(3): 316-329.

Kushwaha, A.K., Gupta, N. \& Chattopadhyaya, M.C. 2017. Adsorption behavior of lead onto a new class of functionalized silica gel. Arabian Journal of Chemistry 10: S81-S89.

Lai, G.S., Lau, W.J., Goh, P.S., Tan, Y.H., Ng, B.C. \& Ismail, A.F. 2019. A novel interfacial polymerization approach towards synthesis of graphene oxideincorporated thin film nanocomposite membrane with improved surface properties. Arabian Journal of Chemistry 12(1): 75-87.

Langmuir, I. 1916. The constitution and fundamental properties of solids and liquids. Part i. solids. Journal of the American Chemical Society 38(11): 2221-2295.

Laskar, I.I., Hashisho, Z., Phillips, J.H., Anderson, J.E. \& Nichols, M. 2019. Competitive adsorption equilibrium modeling of volatile organic compound (VOC) and water vapor onto activated carbon. Separation and Purification Technology 212: 632-640.

Li, K., Zheng, Z., Huang, X., Zhao, G., Feng, J. \& Zhang, J. 2009. Equilibrium, kinetic and thermodynamic studies on the adsorption of 2-nitroaniline onto activated carbon prepared from cotton stalk fibre. Journal of Hazardous Materials 166(1): 213-220.

Li, Z., Hanafy, H., Zhang, L., Sellaoui, L., Netto, M.S., Oliveira, M.L., Seliem, M.K., Dotto, G.L., Bonilla-Petriciolet, A. \& Li, Q. 2020. Adsorption of congo red and methylene blue dyes on an ashitaba waste and a walnut shell-based activated carbon from aqueous solutions: Experiments, characterization and physical interpretations. Chemical Engineering Journal 388: 124263.

Liu, L., Fan, S. \& Li, Y. 2018. Removal behavior of methylene blue from aqueous solution by tea waste: Kinetics, isotherms and mechanism. International Journal of Environmental Research and Public Health 15(7): 1321.

Liu, Q., Liu, Y., Zhang, Z., Wang, X. \& Shen, J. 2020. Adsorption of cationic dyes from aqueous solution using hydrophilic silica aerogel via ambient pressure drying. Chinese Journal of Chemical Engineering 28(9): $2467-$ 2473.

Liu, S., Li, B., Qi, P., Yu, W., Zhao, J. \& Liu, Y. 2019. Performance of freshly generated magnesium hydroxide (FGMH) for reactive dye removal. Colloid and Interface Science Communications 28: 34-40. 
Ma, L.J., Wang, J., Han, M., Jia, J., Wu, H.S. \& Zhang, X. 2019. Adsorption of multiple $\mathrm{H}_{2}$ molecules on the complex $\mathrm{TiC}_{6} \mathrm{H}_{6}$ : An unusual combination of chemisorption and physisorption. Energy 171: 315-325.

Mahmood, A., Khan, S.U.D., Rana, U.A. \& Tahir, M.H. 2019. Red shifting of absorption maxima of phenothiazine based dyes by incorporating electron-deficient thiadiazole derivatives as $\pi$-spacer. Arabian Journal of Chemistry 12(7): 1447-1453.

Marrakchi, F., Hameed, B.H. \& Bouaziz, M. 2020. Mesoporous and high-surface-area activated carbon from defatted olive cake by-products of olive mills for the adsorption kinetics and isotherm of methylene blue and acid blue 29. Journal of Environmental Chemical Engineering 8(5): 104199.

Marrakchi, F., Khanday, W.A., Asif, M. \& Hameed, B.H. 2016. Cross-linked chitosan/sepiolite composite for the adsorption of methylene blue and reactive orange 16 . International Journal of Biological Macromolecules 93: 1231-1239.

Marsin, F.M., Wan Ibrahim, W.A., Nodeh, H.R. \& Sanagi, M.M. 2020. New magnetic oil palm fiber activated carbonreinforced polypyrrole solid phase extraction combined with gas chromatography-electron capture detection for determination of organochlorine pesticides in water samples. Journal of Chromatography A 1612: 460638.

Marwani, H.M., Albishri, H.M., Jalal, T.A. \& Soliman, E.M. 2017. Study of isotherm and kinetic models of lanthanum adsorption on activated carbon loaded with recently synthesized Schiff's base. Arabian Journal of Chemistry 10: S1032-S1040.

Matović, L.L., Vukelić, N.S., Jovanović, U.D., Kumrić, K.R., Krstić, J.B., Babić, B.M. \& Đukić, A.B. 2019. Mechanochemically improved surface properties of activated carbon cloth for the removal of $\mathrm{As}(\mathrm{V})$ from aqueous solutions. Arabian Journal of Chemistry 12(8): 4446-4457.

Nimibofa, A., Ekubo, A., Donbebe, W. \& Dikio, E. 2015 b. Adsorption of congo red by $\mathrm{Ni} / \mathrm{Al}-\mathrm{CO}_{3}$ : equilibrium, thermodynamic and kinetic studies. Oriental Journal of Chemistry 31(3): 1307-1318.

Nippatla, N. \& Philip, L. 2019. Electrocoagulation-floatation assisted pulsed power plasma technology for the complete mineralization of potentially toxic dyes and real textile wastewater. Process Safety and Environmental Protection 125: 143-156.

Odogu, A.N., Daouda, K., Keilah, L.P., Tabi, G.A., Rene, L.N., Nsami, N.J. \& Mbadcam, K.J. 2020. Effect of doping activated carbon based Ricinodendron Heudelotti shells with AgNPs on the adsorption of indigo carmine and its antibacterial properties. Arabian Journal of Chemistry 13(5): 5241-5253.

Pagalan Jr., E., Sebron, M., Gomez, S., Salva, S.J., Ampusta, R., Macarayo, A.J., Joyno, C., Ido, A. \& Arazo, R. 2020. Activated carbon from spent coffee grounds as an adsorbent for treatment of water contaminated by aniline yellow dye. Industrial Crops and Products 145: 111953.

Pathania, D., Sharma, S. \& Singh, P. 2017. Removal of methylene blue by adsorption onto activated carbon developed from Ficus carica bast. Arabian Journal of Chemistry 10: S1445-S1451.

Peng, L.E., Yao, Z., Chen, J., Guo, H. \& Tang, C.Y. 2020. Highly selective separation and resource recovery using forward osmosis membrane assembled by polyphenol network. Journal of Membrane Science 661: 118305.

Rao, L., Yang, Y., Liu, X., Huang, Y., Chen, M., Yao, Y. \& Wang, W. 2020. Heterogeneous activation of persulfate by supporting ferric oxalate onto activated carbon fibers for organic contaminants removal. Materials Research Bulletin 130: 110919.

Rashidi, N.A., Yusup, S., Ahmad, M.M., Mohamed, N.M. \& Hameed, B.H. 2012. Activated carbon from the renewable agricultural residues using single step physical activation: A preliminary analysis. APCBEE Procedia 3: 84-92.

Ringot, D., Lerzy, B., Chaplain, K., Bonhoure, J.P., Auclair, E. \& Larondelle, Y. 2007. In vitro biosorption of ochratoxin A on the yeast industry by-products: Comparison of isotherm models. Bioresource Technology 98(9): 1812-1821.

Saad, M.E.K., Khiari, R., Elaloui, E. \& Moussaoui, Y. 2014. Adsorption of anthracene using activated carbon and Posidonia oceanica. Arabian Journal of Chemistry 7(1): 109-113.

Sabela, M.I., Kunene, K., Kanchi, S., Xhakaza, N.M., Bathinapatla, A., Mdluli, P., Sharma, D. \& Bisetty, K. 2019. Removal of copper (II) from wastewater using green vegetable waste derived activated carbon: An approach to equilibrium and kinetic study. Arabian Journal of Chemistry 12(8): 4331-4339.

Sadhukhan, B., Mondal, N.K. \& Chattoraj, S. 2016. Optimisation using central composite design (CCD) and the desirability function for sorption of methylene blue from aqueous solution onto Lemna major. Karbala International Journal of Modern Science 2(3): 145-155.

Salem, S., Teimouri, Z. \& Salem, A. 2020. Fabrication of magnetic activated carbon by carbothermal functionalization of agriculture waste via microwaveassisted technique for cationic dye adsorption. Advanced Powder Technology 31(10): 4301-4309.

Salman, J.M. 2014. Optimization of preparation conditions for activated carbon from palm oil fronds using response surface methodology on removal of pesticides from aqueous solution. Arabian Journal of Chemistry 7(1): 101-108.

Sartape, A.S., Patil, S.A., Patil, S.K., Salunkhe, S.T. \& Kolekar, S.S. 2015. Mahogany fruit shell: A new low-cost adsorbent for removal of methylene blue dye from aqueous solutions. Desalination and Water Treatment 53(1): 99-108.

Sartape, A.S., Raut, P.D. \& Kolekar, S.S. 2010. Efficient adsorption of vhromium(vi) ions from aqueous solution onto a low-cost adsorbent developed from Limonia 
acidissima (wood apple) shell. Adsorption Science \& Technology 28(6): 547-560.

Schreiter, I.J., Schmidt, W. \& Schüth, C. 2018. Sorption mechanisms of chlorinated hydrocarbons on biochar produced from different feedstocks: Conclusions from singleand bi-solute experiments. Chemosphere 203: 34-43.

Shabaan, O.A., Jahin, H.S. \& Mohamed, G.G. 2020. Removal of anionic and cationic dyes from wastewater by adsorption using multiwall carbon nanotubes. Arabian Journal of Chemistry 13(3): 4797-4810.

Shahmoradi, A.R., Talebibahmanbigloo, N., Javidparvar, A.A., Bahlakeh, G. \& Ramezanzadeh, B. 2020. Studying the adsorption/inhibition impact of the cellulose and lignin compounds extracted from agricultural waste on the mild steel corrosion in $\mathrm{HCl}$ solution. Journal of Molecular Liquids 304: 112751 .

Silva, T.L., Cazetta, A.L., Souza, P.S.C., Zhang, T., Asefa, T. \& Almeida, V.C. 2018. Mesoporous activated carbon fibers synthesized from denim fabric waste: Efficient adsorbents for removal of textile dye from aqueous solutions. Journal of Cleaner Production 171: 482-490.

Sivakumar, S., Muthirulan, P. \& Sundaram, M.M. 2019. Adsorption kinetic and isotherm studies of Azure $A$ on various activated carbons derived from agricultural wastes. Arabian Journal of Chemistry 12(7): 1507-1514.

Sullivan, G.L., Prigmore, R.M., Knight, P. \& Godfrey, A.R. 2019. Activated carbon biochar from municipal waste as a sorptive agent for the removal of polyaromatic hydrocarbons (PAHs), phenols and petroleum based compounds in contaminated liquids. Journal of Environmental Management 251: 109551.

Temkin, M. \& Pyzhev, V. 1940. Kinetics of ammonia synthesis on promoted iron catalysts. Acta Physicochimica URSS 12(1): 217-222.

Üner, O., Geçgel, Ü. \& Bayrak, Y. 2016. Adsorption of methylene blue by an efficient activated carbon prepared from Citrullus lanatus rind: Kinetic, isotherm, thermodynamic, and mechanism analysis. Water, Air, \& Soil Pollution 227(7): 1-15.

Ushiki, I., Sato, Y., Ito, Y., Takishima, S. \& Inomata, H. 2019. A generalized model for predicting adsorption equilibria of various volatile organic compounds on activated carbon in the presence of supercritical carbon dioxide. The Journal of Supercritical Fluids 146: 30-37.

Wang, D., Hu, Q.Y., Li, M., Wang, C. \& Ji, M. 2016. Evaluating the removal of organic fraction of commingled chemical industrial wastewater by activated sludge process augmented with powdered activated carbon. Arabian Journal of Chemistry 9: S1951-S1961.

Wang, K., Peng, N., Sun, J., Lu, G., Chen, M., Deng, F., Dou, R., Nie, L. \& Zhong, Y. 2020. Synthesis of silica-composited biochars from alkali-fused fly ash and agricultural wastes for enhanced adsorption of methylene blue. Science of The Total Environment 729: 139055.

Weber, W.J. \& Morris, J.C. 1963. Kinetics of adsorption on carbon from solution. Journal of the Sanitary Engineering Division 89(2): 31-60.
Widiyastuti, W., Fahrudin Rois, M., Suari, N.M.I.P. \& Setyawan, H. 2020. Activated carbon nanofibers derived from coconut shell charcoal for dye removal application. Advanced Powder Technology 31(8): 3267-3273.

Xu, M.Y., Jiang, H.L., Xie, Z.W., Li, Z.T., Xu, D. \& He, F.A. 2020. Highly efficient selective adsorption of anionic dyes by modified $\beta$-cyclodextrin polymers. Journal of the Taiwan Institute of Chemical Engineers 108: 114-128.

Yao, X., Liu, Y., Li, T., Zhang, T., Li, H., Wang, W., Shen, X., Qian, F. \& Yao, Z. 2020. Adsorption behavior of multicomponent volatile organic compounds on a citric acid residue waste-based activated carbon: Experiment and molecular simulation. Journal of Hazardous Materials 392: 122323.

Yuh-Shan, H. 2004. Citation review of Lagergren kinetic rate equation on adsorption reactions. Scientometrics 59(1): 171-177.

Yusop, M.F.M., Jaya, M.A.T. \& Ahmad, M.A. 2020. Adsorption of anionic remazol brilliant blue $\mathrm{R}$ dye using durian peel based activated carbon via $\mathrm{Na}_{2} \mathrm{CO} 3 / \mathrm{CO}_{2}$ activation. In The Issues in Technologies: Application and Development, edited by Habidin, N.F., Ong, S.Y.Y., Muhamad, U.A. \& Chik, T.W.T. Malaysia: Kaizentrenovation Sdn Bhd. pp. 193-205.

Yusop, M.F.M., Aziz, H.A. \& Ahmad, M.A. 2017. Scavenging remazol brilliant blue $\mathrm{R}$ dye using microwave-assisted activated carbon from acacia sawdust: Equilibrium and kinetics studies. In International Conference on Global Network for Innovative Technology (IGNITE). p. 040018.

Zaini, M.A.A., Zhi, L.L., Hui, T.S., Amano, Y. \& Machida, M. 2021. Effects of physical activation on pore textures and heavy metals removal of fiber-based activated carbons. Materials Today: Proceedings 39: 917-921.

Zhao, Y., Cho, C.W., Wang, D., Choi, J.W., Lin, S. \& Yun, Y.S. 2020. Simultaneous scavenging of persistent pharmaceuticals with different charges by activated carbon fiber from aqueous environments. Chemosphere 247: 125909.

Zhong, Z.Y., Yang, Q., Li, X.M., Luo, K., Liu, Y. \& Zeng, G.M. 2012. Preparation of peanut hull-based activated carbon by microwave-induced phosphoric acid activation and its application in Remazol Brilliant Blue R adsorption. Industrial Crops and Products 37(1): 178-185.

Zhou, R., Zhang, M., Li, J. \& Zhao, W. 2020. Optimization of preparation conditions for biochar derived from water hyacinth by using response surface methodology (RSM) and its application in $\mathrm{Pb}^{2+}$ removal. Journal of Environmental Chemical Engineering 8(5): 104198.

School of Chemical Engineering

Engineering Campus

Universiti Sains Malaysia

14300 Nibong Tebal, Pulau Pinang

Malaysia

*Corresponding author; email: chazmier@usm.my

Received: 29 September 2020

Accepted: 15 December 2020 